\title{
Growth patterns of Western Mediterranean seagrasses: species-specific responses to seasonal forcing
}

\author{
Núria Marbà*, Just Cebrián, Susana Enríquez, Carlos M. Duarte \\ Centre d'Estudis Avançats de Blanes, CSIC, Camí de Santa Bàrbara s/n, E-17300 Blanes (Girona), Spain
}

\begin{abstract}
The seasonal growth pattern of the 4 seagrass species occurring in the NW Mediterranean (i.e. Cymodocea nodosa, Zostera nolti, Z marina, Posidonia oceanical was studied in populations growing in the same locality (Cala Jonquet, Girona, NE Spain), and thus experiencing the same seasonal (i.e. temperature and light) forcing, to evaluate the contribution of species-specific responses to seagrass growth seasonality. C. nodosa, $Z$. noltii, and $Z$. marina showed comparable growth patterns as indicated by significant correlations of growth across species (cross correlation, $r>0.54, p<0.05$ ). This result provided evidence of a similarity in the response of these species to seasonal forcing. The seasonal pattern of $P$. oceanica resembled that of the other species in shoot weight, shoot elongation, and ramet recruitment, whereas it differed in internode weight and rhizome elongation. Despite some similarities in seasonal growth patterns, the patterns were lagged by 1 to 2 mo across species, and the magnitude of seasonal growth fluctuations was species-dependent. Species-specific responses of seagrasses to climate forcing should be related to differences in the capacity of the plants to store resources and to the extent of ramet integration among species, both processes being closely related to plant size. Large seagrasses (e.g. P. oceanica), with thick and long-living rhizomes, should be able to store more photoassimilates and to transport them over longer distances than small plants (e.g. C. nodosa), with thinner and shorter-living rhizomes. Large species should, therefore, be able to grow more independently of environmental conditions than small ones. Moreover, C. nodosa showed the greatest response to temperature fluctuations whereas $Z$. marina growth was strongly coupled to seasonal light conditions, indicating different plant sensitivity to climate fluctuations among species. This study confirms the great variability in seagrass seasonality possible under similar seasonal forcing, and demonstrates that seagrass seasonality has both an extrinsic component, dependent on seasonal forcing of light and temperature, and an intrinsic component. The intrinsic component of seagrass seasonality likely involves a differential capacity of the species to regulate the internal resource economy which may buffer, or amplify, the external seasonal forcing.
\end{abstract}

KEY WORDS: Posidonia oceanica Cymodocea nodosa Z Zostera marina Zostera noltii Seasonality Module size - Module appearance rate Module growth Ramet recruitment Flowering

\section{INTRODUCTION}

Seagrass biomass exhibits high seasonal fluctuations in temperate waters (Duarte 1989). The strong seasonality of temperate seagrass growth has been demonstrated to be coupled to seasonal forcing through

- Present address: Centre for Estuarine and Coastal Ecology. NIOO, Vierstraat 28, 4401 EA Yerseke, The Netherlands. E-mail: marba@nioo.nl correlations between plant growth and seasonal variations in light and temperature (e.g. Sand-Jensen 1975 , Zieman 1975, Jacobs et al. 1982, Phillips et al. 1983، Wium-Andersen \& Borum 1984, Kentula \& McIntire 1986, Terrados 1991, Pérez \& Romero 1992, Olesen \& Sand-Jensen 1994a, Alcoverro et al. 1995). The hypothesis that seasonal variation in seagrass growth exclusively derives from seasonal changes in irradiance and temperature implies that species growing together should exhibit parallel seasonal growth 
dynamics. Yet, seagrass responses to seasonal forcing may also incorporate species-specific effects. These effects may result from different physiological plant responses to light and temperature conditions (Evans et al. 1986), as well as from other intrinsic factors such as the ability to allocate resources to reproduction, leaves or belowground modules, or the differential ability of the species to store and use resources (Ashmun et al. 1982, Pitelka \& Ashmun 1985), which may partially uncouple plant growth from environmental conditions (Pirc 1985). Further, seagrass seasonal responses may be set by internal clocks, rather than reflect direct physiological effects of environmental conditions, rendering seasonal dynamics relatively independent of interannual environmental variability. For instance, there is evidence that the large seagrass Posidonia oceanica is able to maintain its seasonal pattern of leaf production for 2 yr even when growing under constant light, temperature and day length (Ott 1979). Despite the possibility of species-specific effects on seagrass growth seasonality this aspect remains untested, perhaps because temperate seagrass stands, unlike those in the tropics, are mostly monospecific.

There are 4 seagrass species growing in the Western Mediterranean. Posidonia oceanica (L.) Delile and, in sheltered bays, Cymodocea nodosa (Ucria) Aschers. are dominant. Zostera noltii Hornem. occurs in shallow, protected bays and lagoons, and $Z$. marina L. is restricted to brackish lagoons and some sheltered coves (den Hartog 1970). The growth seasonality of $P$. oceanica (Ott 1980, Cayé \& Rossignol 1983, Bãy 1984, Wittman 1984, Romero 1985, Buia et al. 1992, Alcoverro et al. 1995) and C. nodosa (Pérez 1989, Peduzzi \& Vukovic 1990, Terrados \& Ros 1992) has been described for plants growing in different locations in the Mediterranean region. Seasonality of $Z$. marina and $Z$. noltii growth has been observed in populations in the Atlantic Ocean (Sand-Jensen 1975, Jacobs 1979, Nienhuis \& De Bree 1980, Robertson \& Man 1984, ThorneMiller \& Harlin 1984, Wium-Andersen \& Borum 1984, Orth \& Moore 1986, Vermaat et al. 1987, Roman \& Able 1988, Pedersen \& Borum 1993, Pérez-Llorens \& Niell 1993, Olesen \& Sand-Jensen 1994a) and other seas (e.g. the Pacific; Backman \& Barilotti 1976, Aioi 1980, Mukai et al. 1980, Kentula \& McIntire 1986, Ibarra-Obando 1989, Thom 1990), but it has never been examined in the Mediterranean Sea, except for a description of seasonal changes in $Z$. noltii biomass (Pérez 1989). The discovery of a location in the NW Mediterranean where all 4 species grow together (Cala Jonquet, NE Spain, $42^{\circ} 18.26^{\prime} \mathrm{N}, 3^{\circ} 18.11^{\prime} \mathrm{E}$ ) offered an opportunity to test for the species-specific aspects of seagrass growth. seasonality.

Here we examine seasonal fluctuations in the growth of all seagrass species occurring in the NW
Mediterranean (Cymodocea nodosa, Zostera noltii, Z. marina, Posidonia oceanica) by analysing seasonal variation in the weight, formation rate and growth of modules (i.e. leaf, flower, rhizome internode, root; White 1979) and ramets in the same location (Cala Jonquet). This similarity in seasonal conditions allowed us to quantify the importance of intrinsic factors (e.g. plant sensitivity to seasonal conditions, and ability to allocate, store and use resources) on seagrass growth seasonality. Moreover, we provide here a first account of the dynamics of seasonal growth of $Z$. noltii and $Z$. marina in the Mediterranean.

\section{METHODS}

The growth of Cymodocea nodosa, Zostera noltii, $Z$. marina and Posidonia oceanica was studied in Cala Jonquet, a protected cove where ail 4 seagrass species present in the NW Mediterranean coast occur (Fig. 1). $P$. oceanica grows from $2 \mathrm{~m}$. to often around $16 \mathrm{~m}$ depth, forming a continuous monospecific meadow. $C$. nodosa and $\vec{Z}$. noilii uevelop a mixcd meadow in the shallow $(<1.5 \mathrm{~m})$ part of the cove, where changes in the sea level sporadically expose the shallow margins of the seagrass meadow. $Z$. marina grows in 2 small patches in the shallow part of the cove (Fig. 1). All species were sampled at the depth of maximal shoot density. This depth was $4 \mathrm{~m}$ for P. oceanica and $1 \mathrm{~m}$ for all other species. Nutrient concentrations in the water were relatively low (annual average $1.1 \mu \mathrm{mol} \mathrm{I}^{-1}$ of nitrate, $1.4 \mu \mathrm{mol} \mathrm{l^{-1 }}$ of ammonium and $0.3 \mu \mathrm{mol} \mathrm{l^{-1 }}$ of phosphate), and they did not fluctuate seasonally (Vidondo \& Duarte 1995).

We sampled, at monthly intervals between September 1991 and June 1993, the Cymodocea nodosa, Zostera noltii and Posidonia oceanica populations. $P$. oceanica was sampled every other month during 1993. The finding of $2 Z$. marina patches in April 1992 allowed monthly sampling of this species to be conducted until August 1993. During each visit, we marked 10 apices of the horizontal rhizomes of each species by placing a plastic tag around the last horizontal rhizome internode produced and marking the adjacent leaf sheaths. We marked the adjacent leaf sheaths by punching a hole through the leaves, at the level of their leaf sheaths, with a hypodermic needle (Pérez et al. 1991). Because P. oceanica and C. nodosa have horizontal and vertical rhizomes (i.e. short shoots; Tomlinson 1974) that grow at different rates (Duarte et al. 1994), the latter producing most of the leaves, we also marked 10 to 15 vertical rhizomes of these species by marking the leaves as described above. We then collected the plant material marked during the previ. ous visit and more than 100 supplementary ramets of 


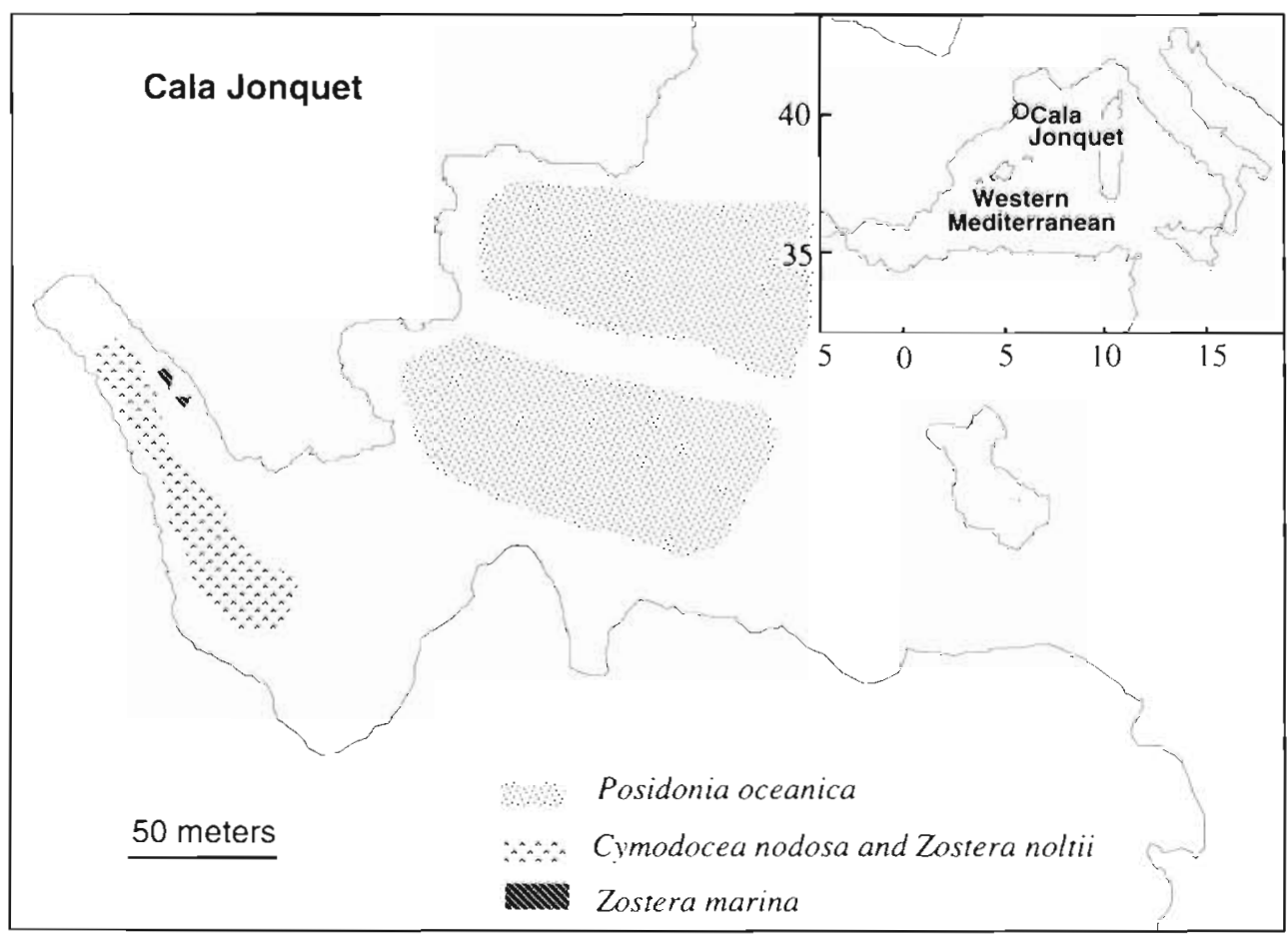

Fig. 1 Location of the sedgrass populations studied

$C$. nodosa and $Z$. noltii within three $20 \mathrm{~cm}$. diameter cores, and we harvested, individually, about 50 supplementary ramets of $P$. oceanica and $Z$. marina. In the laboratory, we recorded the number of new modules (leaf, flower, rhizome internode, root) and ramets that appeared during the marking period, and the length of new growth of the marked plant material (leaves and rhizomes). We measured, after overnight desiccation at $85^{\circ} \mathrm{C}$, dry weight of leaf clusters (hereafter referred to as shoots) and of new rhizome internodes of all species, and that of the new roots produced on the tagged rhizomes of $C$. nodosa, Z noltii and $Z$. marina. We recorded the fraction of flowering ramets of each species in the supplementary ramets collected, and weighed a sample of dried inflorescences. These measurements allowed examination of annual changes in module size, in the rate of module and ramet appearance, and in module growth.

New leaves were identified by unmarked young leaves, and new horizontal rhizome internodes, new ramets and new roots were identified as those which developed between the horizontal rhizome apex and the plastic tag. The rate of appearance of leaves per shoot, and, similarly, the rate of appearance of horizontal rhizome internodes and ramets per rhizome apex, were calculated as

Rate of appearance of leaves $=$

No. of new leaves in a shoot/ $T$

where $T$ was the number of days in the marking pe- riod. Leaf, rhizome, and root growth were estimated as Leaf elongation rate $=$ (Length of new leaves +

Elongation of old leaves) produced per shoot/ $T$

Rhizome elongation rate $=$

Length of horizontal rhizome produced by an apex/ $T$ and

Root production rate $=$

Weight of new roots produced by an apex/ $T$

These measurements underestimate leaf elongation rate of Cymodocea nodosa, and Zostera spp. during peak growth, when $>1$ leaf was lost. They underestimate, by about $10 \%$, rhizome elongation rate of $C$. nodosa and $Z$. noltii in July, and of $Z$. marina in September, when there was some growth of the youngest rhizome internode after it was produced. Root growth is also underestimated because the measurements do not account for growth of old roots, nor for root production on vertical rhizomes of C. nodosa.

Daily incident irradiance was obtained from a station $21 \mathrm{~km}$ south of the study site (Experimental Research Station Mas Badia, St. Pere Pescador). Surface water temperature was measured weekly at a location $27 \mathrm{~km}$ south of the study site (L'Estartit; J. Pascual unpubl. data). We cumulated the daily incident irradiance data over each month, whereas we used the monthly average water temperature.

We used the coefficient of variation to represent the extent of the variability of module size and dynamics 


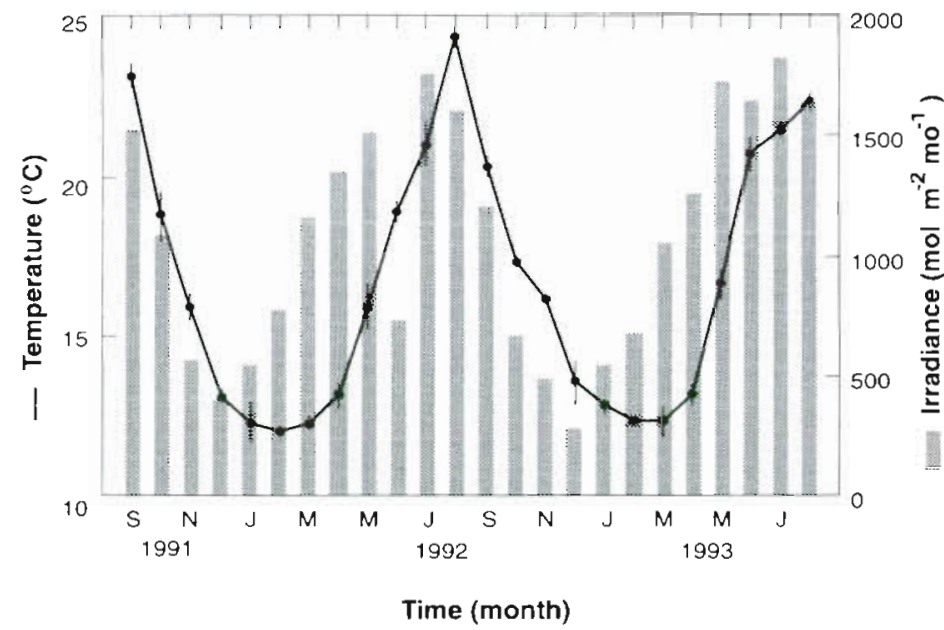

Fig. 2. Monthly variation in surface sea temperature $(--)$ and cumulative solar irradiance per month (bars) during the study period in the NW Mediterranean

over the year. The plant response to seasonal forcing, described by solar irradiance and water temperature, was examined using cross correlation analysis to allow for lagged responses between seasonal changes and plant dynamics. The strength of the coupling between seasonal changes and plant response was represented by the coefficient of determination $\left(R^{2}\right.$, i.e. the percent of annual variance in module size and dynamics statistically accounted for by variation in temperature or irradiance). Cross correlation analysis was also used to examine the similarity of the seasonal growth patterns across species.

\section{RESULTS}

The irradiance received at the water surface ranged from $269 \mathrm{~mol}$ photons $\mathrm{m}^{-2} \mathrm{mo}^{-1}$ in December to $1824 \mathrm{~mol}$ photons $\mathrm{m}^{-2} \mathrm{mo}^{-1}$ in July (Fig. 2). Irradiance fluctuations were similar in 1992 and 1993, but very low irradiance occurred in June 1992, due to a long storm period (Fig. 2). This anomaly, however, was not reflected in the water temperature, which produced a smooth annual pattern, with a minimum of $12^{\circ} \mathrm{C}^{-}$, in February and a maximium of $23.2^{\circ} \mathrm{C}$, in September (Fig 2). Water temperature lagged changes in irradiance by about 1 mo (cross correlation, lag $=1 \mathrm{mo}$,
Shoot (g DW)

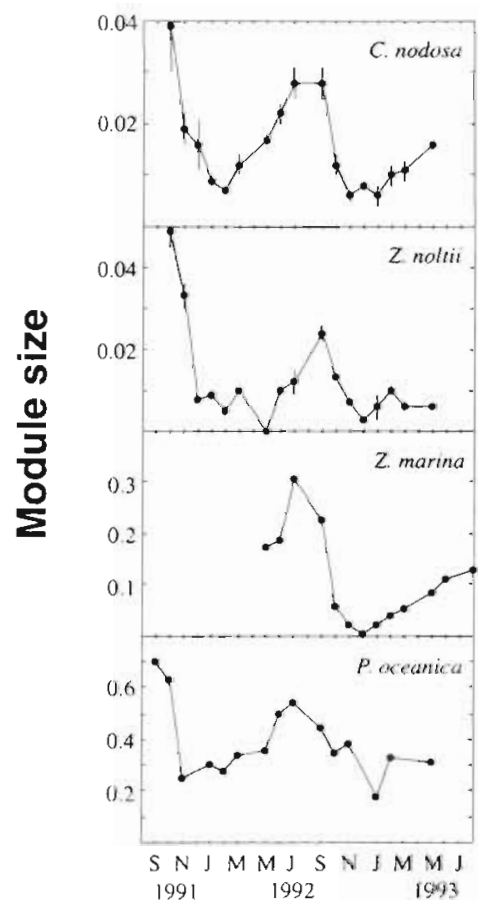

Horizontal internode (g DW)

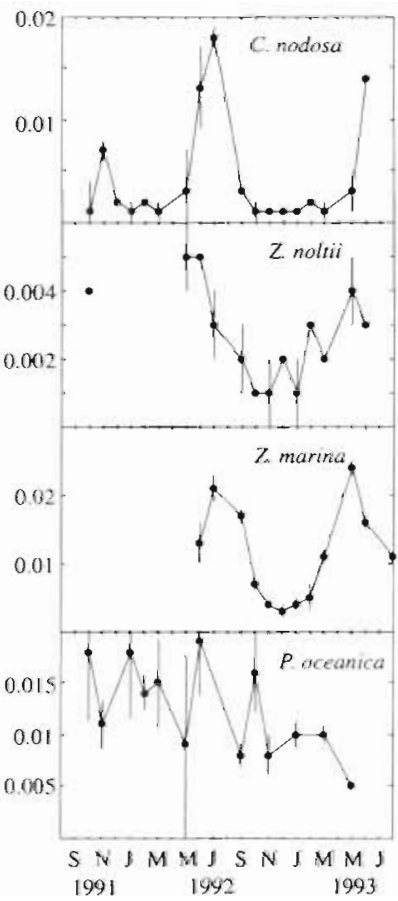

Root (g DW internode ${ }^{-1}$ )

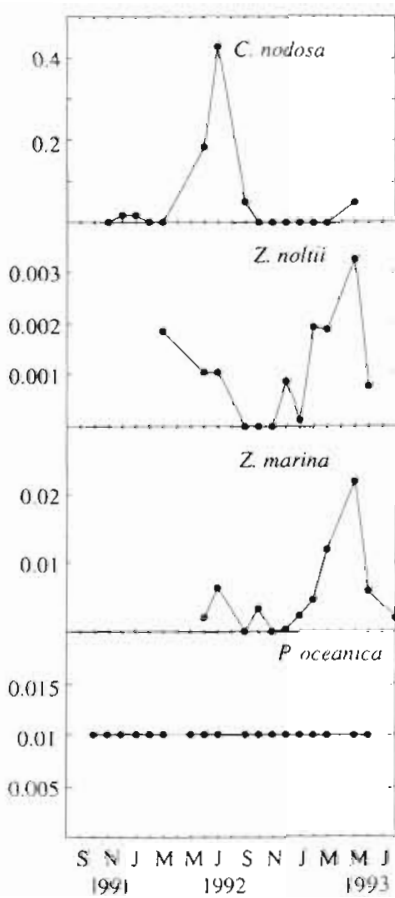

Flower (g DW)

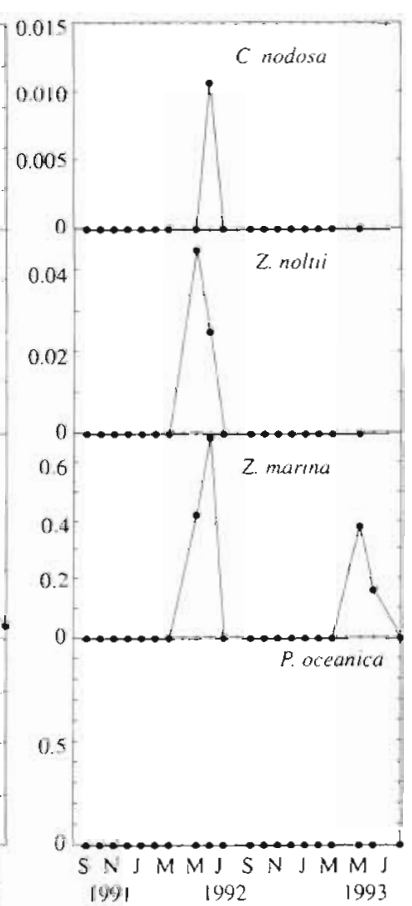

\section{Time (months)}

Fig. 3. Seasonal changes in seagrass module size. Bars represent the standard error of the mean; no bars drawn for pooled measurements (i.e. at least 10 modules weighted together) 
$r=0.87, \mathrm{p}<0.051$. Water transparency was higher in spring-summer than in winter, but it always exceeded $>9 \mathrm{~m}$ depth ( $\mathrm{J}$. Pascual unpubl. data).

All seagrass species growing in Cala Jonquet flowered between May and June, except for Posidonia oceanica, which did not flower during the study period. Zostera marina produced the largest inflorescences (0.39 $\mathrm{g} \mathrm{DW}$ ) and in considerable abundance during the flowering period $19 \%$ of shoots flowered per year). C. nodosa produced small inflorescences (i.e. $0.029 \mathrm{~g}$ dry weight, DW) but flowered profusely (23\% of the shoots flowered per yeari, and flowering of $Z$. noltii $(0.072 \mathrm{~g} \mathrm{DW}$ inflorescence $^{-1}$ ) was scarce ( $1 \%$ of the shoots flowered per year). Though we did not find any inflorescences of $P$. oceanica, we identified inflorescence peduncles (cf. Pergent et al. 1989 ) on its shoots (0.01 peduncles shoot ${ }^{-1}$ ). indicative of flowering events in past years.

The weight of the vegetative modules produced by these seagrasses varied greatly over the year (Figs. $3 \& 4$ ). Posidonia oceanica was the largest species, with the largest shoots and roots, though horizontal internodes were small. Zostera marina was also large, but its roots were much smaller than those of Cymodocea nodosa. The shoots of $Z$. marina were smaller in this nutrient-poor Mediterranean Bay than those normally reported for the Atlantic populations (e.g. McRoy 1966, Phillips 1972, Lalumière et al. 1994), whereas the reverse applied to $Z$. noltii, which grew subtidally here but mostly occupies the intertidal zone in the Atlantic region (e.g. Vermaat et al. 1987, PérezLlorens 1991).

The lowest annual variability in module size was observed in Posidonia oceanica (Fig. 4). Zostera spp. showed the widest fluctuations in the size of seagrass shoots, whereas the annual variability in the size of belowground modules (i.e. horizontal rhizome internodes and roots) was greatest in Cymodocea nodosa (Fig. 4). The size of the vertical rhizome internodes of $P$ oceanica and $C$. nodosa also changed during the year with much greater changes in C. nodosa $(\mathrm{CV}=56.5 \%)$ than in $P$. oceanica $(\mathrm{CV}=$ $6.5 \%$ ).

All species experienced similar annual fluctuations in shoot weight, and Cymodocea nodosa and Zostera marina shared similar patterns in horizontal internodal

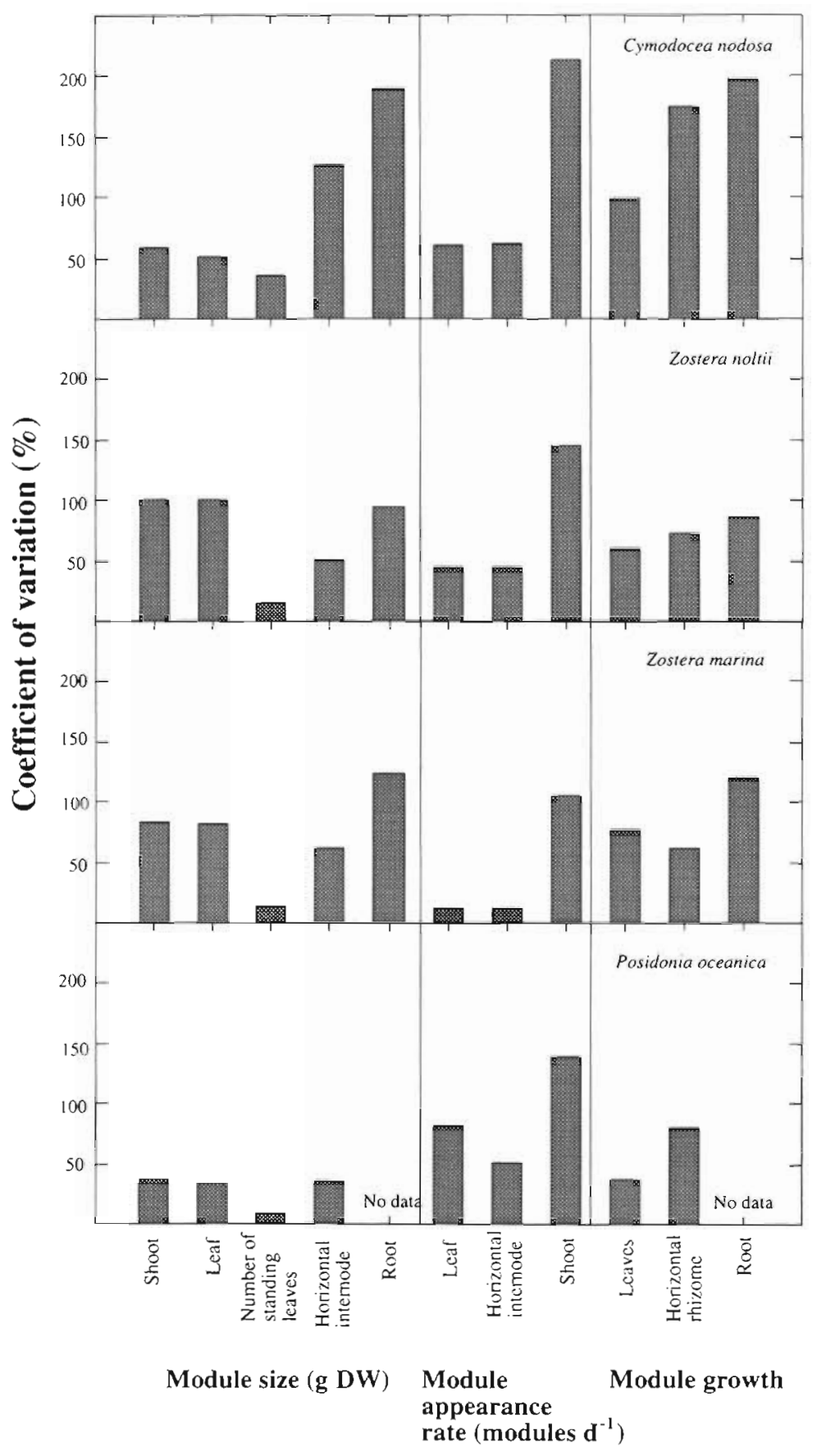

Fig. 4. Magnitude of annual fluctuations in module size, appearance rate and growth for the 4 seagrass species studied

weight as well (Table 1). The plants carried the largest shoots, and produced the heaviest rhizome internodes, in summer and the smallest and lightest ones in winter, although for $Z$. noltii this pattern was delayed (relative to shoots of $Z$. marina) by 1 mo (Fig. 3, Table 1). C. nodosa root weight showed seasonal changes, with the largest roots in summer (Fig. 3), the time of greatest nutrient demands (S. Enríquez et al. unpubl. results). 
Table 1. Cymodocea nodosa, Zostera marina, Z. noltii and Posidonia oceanica. Cross correlation analysis of seasonal patterns between seagrass species in the NW Mediterranean. Negative and positive lags indicate the extent to which the seasonal pattern of the first species is delaved or advanced, respectively, relative to that of the second; lag: time in months for maximal correlation;

r: Pearson coefficient (after log transformation, when necessary); ns: non-sıgnificant correlatıon ( $p>0.05$ ); nd: no data

\begin{tabular}{|c|c|c|c|c|c|c|}
\hline Variable & $\begin{array}{l}\text { C. nodosa- } \\
\text { Z. noltii }\end{array}$ & $\begin{array}{l}\text { C. nodosa- } \\
\text { 7. marina }\end{array}$ & $\begin{array}{l}\text { P. oceanica- } \\
\text { C. nodosa }\end{array}$ & $\begin{array}{l}\text { Z. nolti- } \\
\text { Z. marina }\end{array}$ & $\begin{array}{l}\text { P. oceanica- } \\
\text { Z. noltii }\end{array}$ & $\begin{array}{l}\text { P. oceanica } \\
\text { Z. marina }\end{array}$ \\
\hline \multicolumn{7}{|c|}{ Shoot size (g DW) } \\
\hline Lag & 0 & 0 & 0 & -1 & 0 & 0 \\
\hline r & 0.762 & 0.544 & 0.667 & $0.319 \mathrm{~ns}$ & $0.430 \mathrm{~ns}$ & $0.380 \mathrm{~ns}$ \\
\hline $\mathrm{SE}$ & 0.242 & 0.236 & 0.236 & 0.250 & 0.236 & 0.229 \\
\hline \multicolumn{7}{|c|}{ Horizontal internode size (g DW) } \\
\hline Lag & -1 & 0 & -1 & 1 & 0 & 0 \\
\hline r & $0.381 \mathrm{~ns}$ & 0.540 & $0.270 \mathrm{~ns}$ & $0.430 \mathrm{~ns}$ & $0.420 \mathrm{~ns}$ & $0.641 \mathrm{~ns}$ \\
\hline $\mathrm{SE}$ & 0.243 & 0.236 & 0.250 & 0.243 & 0.243 & 0.236 \\
\hline \multicolumn{7}{|c|}{ Root size (g DW internode ${ }^{-1}$ ) } \\
\hline Lag & 3 & -2 & nd & 0 & nd & nd \\
\hline r & $-0.528 \mathrm{~ns}$ & $0.836 \mathrm{~ns}$ & & $0.816 \mathrm{~ns}$ & & \\
\hline $\mathrm{SE}$ & 0.277 & 0.258 & & 0.277 & & \\
\hline \multicolumn{7}{|c|}{ Horizontal internode appearance rate [iniernodes (horizontal ihizome) ${ }^{-1} \mathrm{~d}^{-1}$ ] } \\
\hline Lag & 0 & 0 & -2 & 0 & -3 & 0 \\
\hline r & $0.468 \mathrm{~ns}$ & 0.561 & $0.377 \mathrm{~ns}$ & $0.186 \mathrm{~ns}$ & $0.368 \mathrm{~ns}$ & $0.226 \mathrm{~ns}$ \\
\hline SE & 0.236 & 0.236 & 0.258 & 0.236 & 0.267 & 0.236 \\
\hline \multicolumn{7}{|c|}{ Leaf appearance rate (leaves shoot ${ }^{-1} \mathrm{~d}^{-1}$ ) } \\
\hline Iag & 0 & 0 & -2 & 0 & -2 & -2 \\
\hline r & 0.541 & $0.349 \mathrm{~ns}$ & 0.647 & $0.186 \mathrm{~ns}$ & $0.374 \mathrm{~ns}$ & $0.231 \mathrm{~ns}$ \\
\hline $\mathrm{SE}$ & 0.243 & 0.236 & 0.289 & 0.236 & 0.289 & 0.277 \\
\hline \multicolumn{7}{|c|}{ Ramet recruitment [ramets (horizontal rhizome) ${ }^{-1} \mathrm{~d}^{-1}$ ] } \\
\hline Lag & -1 & 0 & 2 & 1 & -1 & 0 \\
\hline r & $0.389 \mathrm{~ns}$ & 0.531 & 0.324 & 0.616 & 0.531 & $0.278 \mathrm{~ns}$ \\
\hline $\mathrm{SE}$ & 0.243 & 0.236 & 0.258 & 0.243 & 0.250 & 0.236 \\
\hline \multicolumn{7}{|c|}{ Leaf elongation rate $\left(\mathrm{cm} \mathrm{shoot}{ }^{-1} \mathrm{~d}^{-1}\right)$} \\
\hline Lag & 1 & 0 & 1 & -1 & 2 & 1 \\
\hline r & 0.792 & 0.765 & 0.560 & 0.704 & $0.574 \mathrm{~ns}$ & 0.649 \\
\hline $\mathrm{SE}$ & 0.250 & 0.243 & 0.277 & 0.250 & 0.289 & 0.267 \\
\hline \multicolumn{7}{|c|}{ Rhizome elongation rate $\left.[\mathrm{cm} \text { (horizontal rhizome })^{-1} \mathrm{~d}^{-1}\right]$} \\
\hline Lag & -1 & 0 & -2 & 1 & -3 & -2 \\
\hline r & 0.821 & 0.615 & $0.247 \mathrm{~ns}$ & $0.473 \mathrm{~ns}$ & $0.325 \mathrm{~ns}$ & 0.620 \\
\hline SE & 0.243 & 0.236 & 0.258 & 0.243 & 0.267 & 0.250 \\
\hline \multicolumn{7}{|c|}{ Root production $\left.[\mathrm{g} D W \text { (horizontal rhizome })^{-1} \mathrm{~d}^{-1}\right]$} \\
\hline Lag & -1 & -1 & nd & 0 & nd & nd \\
\hline T & 0.655 & $0.435 \mathrm{~ns}$ & & 0.776 & & \\
\hline SE & 0.258 & 0.250 & & 0.277 & & \\
\hline
\end{tabular}

This increase of $C$. nodosa root weight might reflect phosphorus limitation of plant growth in summer, since there is evidence that phosphorus-limited $C$. nodosa allocates more biomass to root development to increase the capacity of roots to acquire phosphorus from the sediment (Pérez et al. 1995). The largest roots in $Z$. noltii and $Z$. marina were observed in spring (Fig. 3).

The overall similarity in the seasonal fluctuations of module size for all 4 species suggests that they might respond to similar factors, such as seasonal changes in water temperature and irradiance. Variability in water temperature explained most $\left(\mathrm{R}^{2}>50 \%\right.$; Fig. 5) of the annual variability of seagrass shoot weight for all species, except for Zostera noltii $\left(R^{2}=0.24\right.$; Fig 5). The seasonal changes in the size of horizontal rhizome internodes were partially attributable ( $>40^{\prime \prime}$.) to seasonal variability in temperature (Cymodocea nodosa; Fig. 5) and light (Z. marina; Fig. 6). Changes in vertical internode length were independent of seasonal variability in temperature and irradiance (cross correlation, $p>0.5$ ), suggesting that other non-seasonal environmental factors (e.g sediment dynamics) may influence their size (cf. Marbà \& Duarte 1994, Marbà et al. 1994). Root size was correlated with temperature only for $C$. nodosa.

The rate of module reiteration in these seagrass populations fluctuated over the year (CV from 1.3 to $213 \%$; Figs. $4 \& 7$ ). The greatest seasonal variability in leaf 
appearance rate was observed in Posidonia oceanica. The amplitude of seasonal fluctuations in the production of new horizontal internodes was similar among species, apart from Zostera marina (Figs. 4 \& 7). All species, except $Z$. marina, followed similar patterns of leaf formation rate (Table 1), with maximum rates of leaf formation attained in September (Fig. 7). Z. marina produced new leaves and new horizontal internodes at a remarkably constant (and high) rate over the year (Figs. $4 \& 7$ ), particularly when compared with $Z$. marina populations growing in the Atlantic (SandJensen 1975, Wium-Andersen \& Borum 1984, Olesen \& Sand-Jensen 1994a), and it did not show any seasonal trend. Ramet recruitment showed large seasonal fluctuations ( $\mathrm{CV}>100 \%$, Figs. 4 \& 7) and revealed the existence of a single cohort (i.e. a single period of ramet recruitment) per year, in spring or early summer, in all species except for $Z$. noltii. $Z$. noltii appeared to produce several cohorts from spring to autumn. Ramet recruitment patterns were significantly correlated, but lagged 1 or 2 mo, among species (Table 1 ).

The similar patterns of leaf formation rate among the species were associated ( $>50 \%$ of the variance) with fluctuations in temperature and irradiance (Figs. 5 \& 6). This correlation was strongest for the larger species (Posidonia oceanica and Cymodocea nodosa) than for the small Zostera noltii (Figs. 5 $\&$ 6). Seasonal variability in temperature accounted for the seasonality in the rate of horizontal internode formation of C. nodosa and $Z$. noltii (Figs. 5 \& 6). Ramet recruitment was strongly associated with seasonal variation in temperature and irradiance only for C. nodosa and Z. marina (Figs. 5 \& 6). Ramet recruitment was coupled $(r=0.60,0.67$ and $0.89, p<0.05$, for $P$. oceanica, $Z$. marina and $C$. nodosa, respectively) to the rate of appearance of horizontal internodes, with a lag of 4 mo between maximal rates of appearance of horizontal internodes and shoot recruitment in $P$. oceanica. This delay in $P$. oceanica ramet recruitment, relative to horizontal rhizome appearance, could derive from the difficulty in identifying new ramets when they start to develop (i.e. $<2$ leaves or, on average, 3.8 mo old).

Seagrass growth of all 4 seagrass species varied over the year (Fig. 8). The extent of seasonal variation in
Plant response to temperature

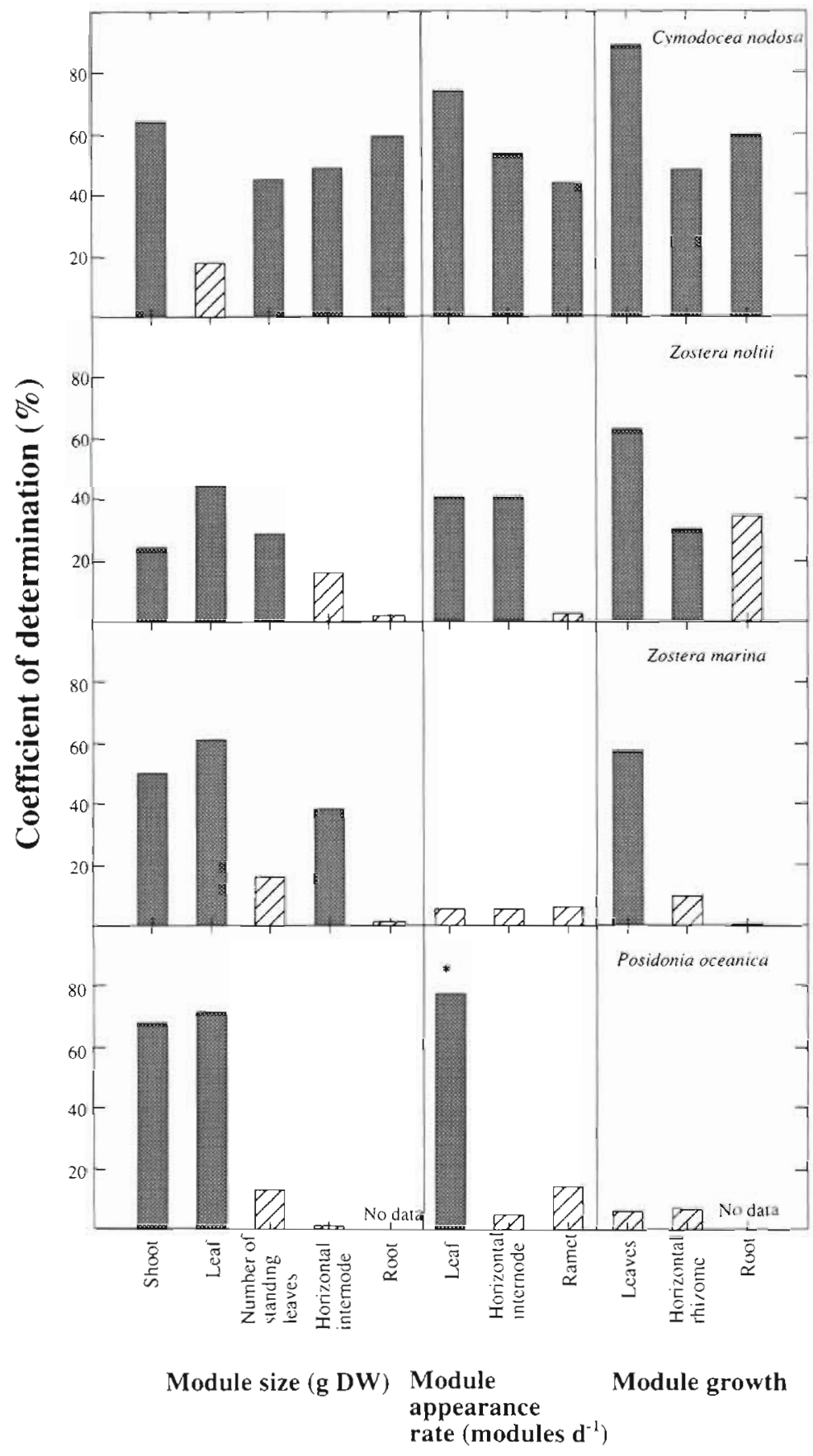

Fig. 5. Coefficients of determination for the relationships of seagrass module size, appearance rate, and growth [units for leaf growth are $\mathrm{cm} \mathrm{shoot}{ }^{-1} \mathrm{~d}^{-1}$, for thizome growth $\mathrm{cm}$ (horizontal rhizome apex) ${ }^{-1} \mathrm{~d}^{-1}$, and for root growth g DW (horizontal rhizome apex) $\left.{ }^{-1} \mathrm{~d}^{-1}\right)$ ] to water temperature conditions. Shaded bars indıcate significant relationships $(\mathrm{p}<0.05)$, hatched bars indicate non-significant $(p>0.05)$ relationships. $\cdot$ Relationship lagged by 2 mo

seagrass growth was greatest in belowground modules (horizontal rhizomes and roots) as compared to leaves (Fig 4). The allocation of growth to aboveground or 


\section{Plant response to light}

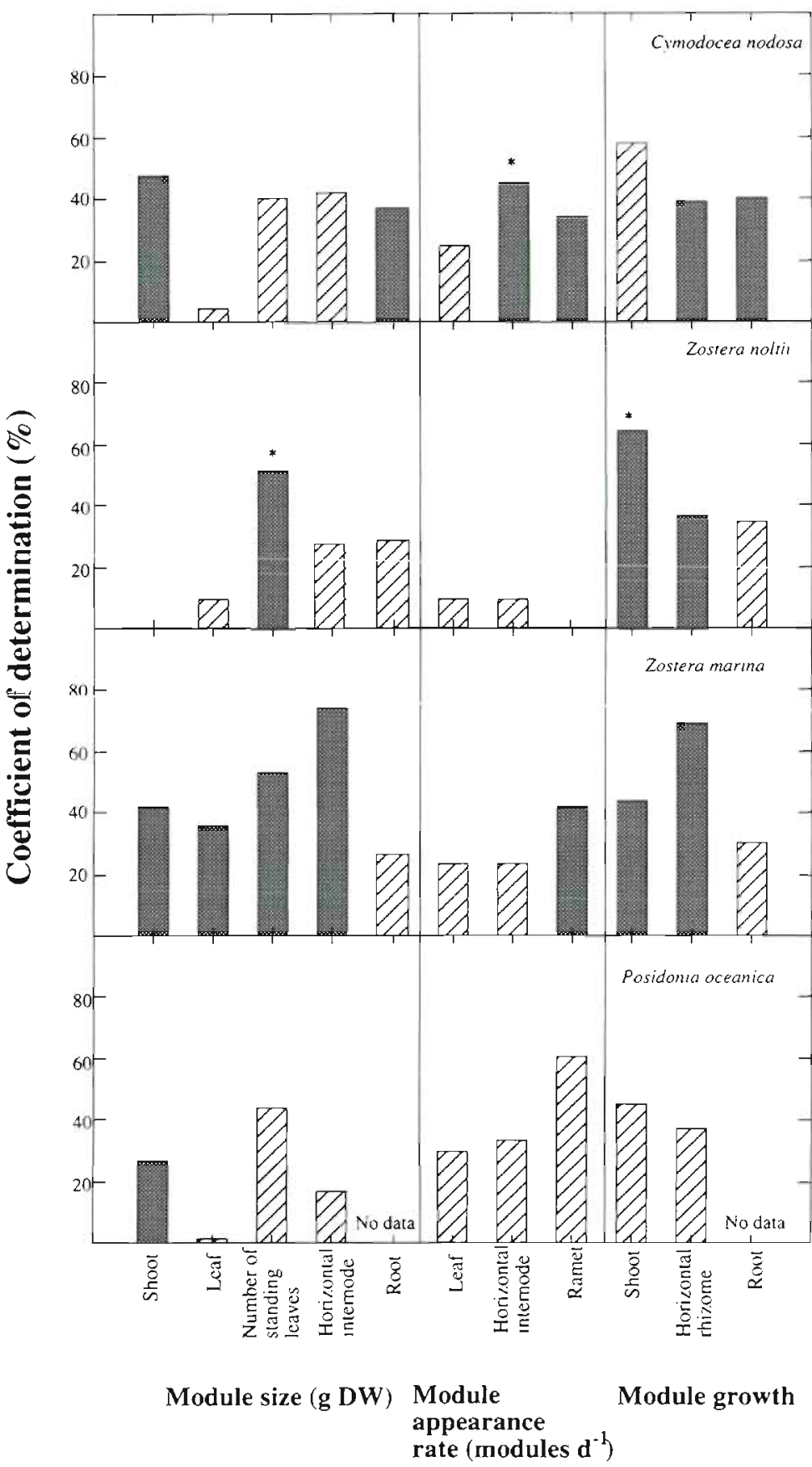

Fig. 6. Coefficients of determination for the relationships between seagrass module size, appearance rate and growth (units for leaf growth are $\mathrm{cm} \mathrm{shoot}^{-1}$ $\mathrm{d}^{-1}$, for rhizome growth $\mathrm{cm}$ (horizontal rhizome apex) - $^{-1} \mathrm{~d}^{-1}$, and for root growth g DW (horizontal rhizome apex) $)^{-1} \mathrm{~d}^{-1}$ l and surface irradiance. Shaded bars indicate significant relationships $(p<0.05)$, hatched bars indicate nonsignificant $(p>0.05)$ relationships. "Relationship lagged by 1 mo

belowground modules was species-sperific, with Zostera marina showing the greatest leaf growth, and Cymodocea nodosa the highest rhizome and root growth rates (Fig. 8). Posidonia oceanica experienced the smallest variability in plant growth (Figs. 4 \& 8). Seasonal variation in the leaf elongation rate in the shoots of all species followed the same pattern (Table 1), with the maximum growth occurring in summer and the minimum in winter (Fig. 8, Table 1), but delayed by 1 mo in $Z$. noltii. A similar pattern was observed in the horizontal rhizome elongation of $C$. nodosa, $Z$. noltii and $Z$. marina, though maximum elongation of $Z$. noltii occurred 1 mo earlier than in $C$. nodosa and $Z$. marina (Fig. 8, Table 1). Variability in rhizome elongation also induced changes in root production, with a similar seasonal pattern in these 3 species. Maximum rhizome elongation and root production were also reached 1 mo earlier in $Z$. noltii (Table 1). The rhizome elongation rate of $P$. oceanica was maximal during fall and minimal in spring (Fig. 8).

The paitent ubserved in scagrass growth, except that in Posidonia oceanica, closely correlated $(r>0.70, p<0.05)$ with seasonal fluctuations in climate conditions. However, seagrass growth in one species (i.e. Cymodocea nodosa) was mainly correlated with temperature fluctuations, while others (i.e. Zostera noltii and Z marina; Figs. $5 \& 6$ ) tracked the light variability more closely. Seasonality in root production was observed only in $C$. nodosa and it was strongly ( $60 \%$ of the variance) correlated to temperature (Fig. 5). The absence of substantial correlations between annual growth of $P$. oceanica and external forcing (i.e. light and temperature) suggests that the seasonality of this species is strongly constrained by internal factors.

\section{DISCUSSION}

The results demonstrate distinct seasonal growth patterns among the 4 seagrass species that occur in the NW Mediterranean, and the importance of species-specific responses to seasonal forcing The significant correlations between the seasonal. growth patterns of the different species (Table 1) demonstrate that environmental forcing imposes a general, and similar, trend of growth seasonality in species growing at the same site. Yet, the seasonal growth peaks displayed by seagrasses 
Fig. 7 Seasonal changes in the rate of appearance of seagrass modules
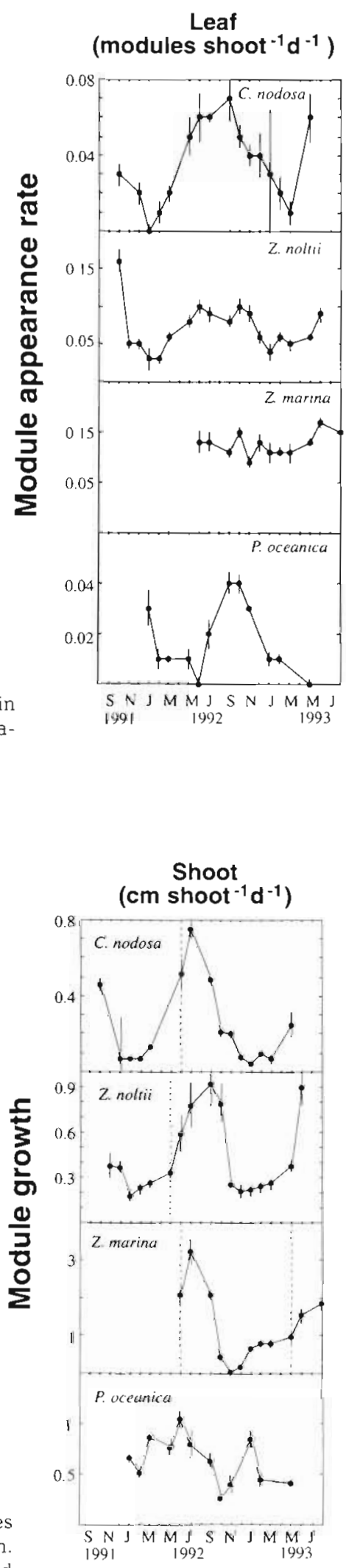

Fig. 8. Seasonal changes in seagrass module growth Dashed lines indicate period of maximal flowering

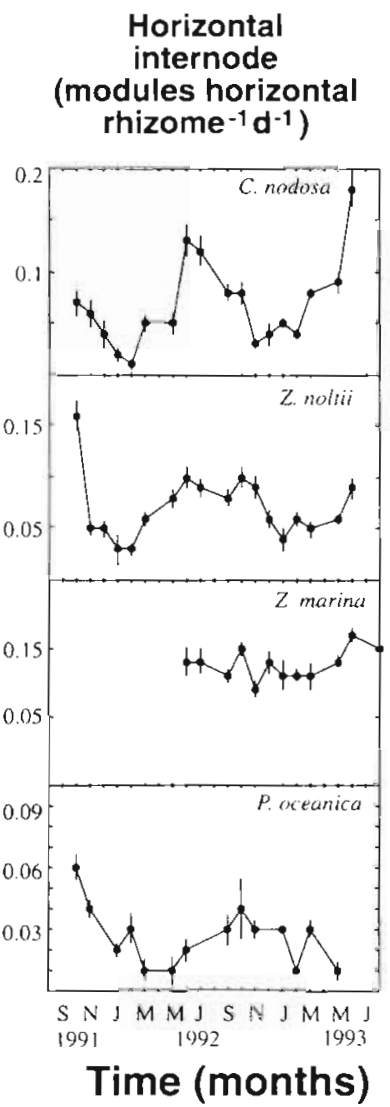

Ramet

(ramets horizontal rhizome $\mathrm{m}^{-1} \mathrm{~d}^{-1}$ )

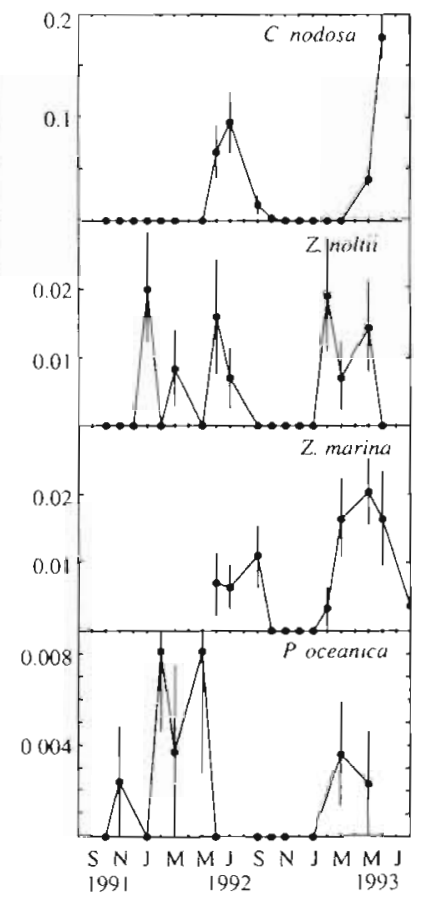

1991 (cm horizontal rhizome ${ }^{-1} d^{-1}$ )

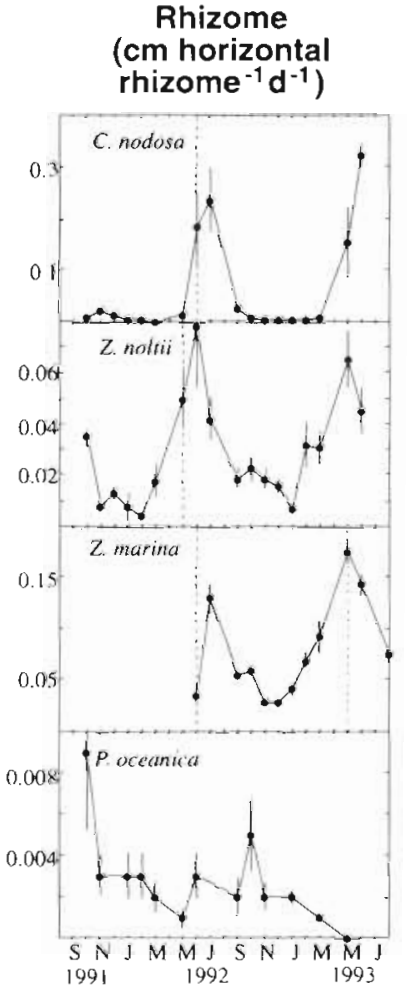

Time (months)

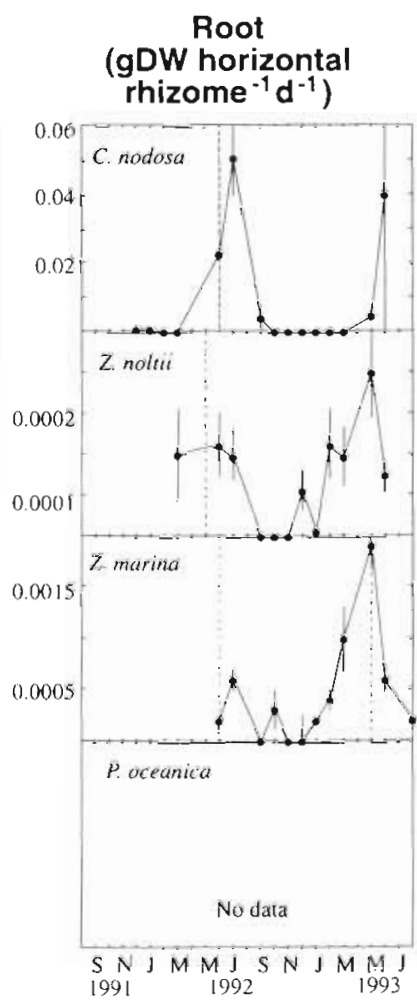


differed by 1 to 2 mo when compared across species (Table 1). This finding, and the great species differences in the amplitude of seasonal growth fluctuations (Fig. 4), reveal an important intrinsic component of seagrass growth seasonality. Hence, climatic seasonality should largely determine the annual variability in seagrass seasonal growth dynamics, but the timing and the magnitude of plant responses should be species-dependent. The existence of species-specific responses of seagrasses to changes in seasonal forcing has been also observed in Zostera marina and Ruppia maritima coexisting in Chesapeake Bay, USA, where they displayed different physiological responses to changes in temperature and light (Evans et al. 1986). In addition, there is a local component of seagrass seasonality, not attributable to species-specific responses, which derives from local variability in resource availability (nutrients and dissolved inorganic carbon) and other local conditions (e.g. redox potential; Alcoverro et al. 1995).

The species most sensitive to seasonal fluctuations was Cymodocea nodosa. C. nodosa module size and growth were strongly coupled to climatic conditions, particularly temperature, while Posidonia oceanica was the species least responsive to seasonal fluctuations (Figs. $5 \& 6$ ). Hence, the growth pattern of $P$. oceanica was relatively independent of environmental conditions when compared to those of the other species examined, albeit it grew under slightly more uniform annual light and temperature conditions, due to the greater depth, than the other species. The seasonal growth patterns of $C$. nodosa, $P$. oceanica, and Zostera noltii were primarily associated with temperature changes while that of $Z$. marina was best related to the average irradiance (Figs. $5 \& 6$ ). The differential association of the seagrass species with light or temperature contributes to the moderate differences in their seasonal development. The specific sensitivity of seagrass growth to light and temperature observed here is in agreement with those observed for populations growing in other localities, supporting the idea of species-specific responses to seasonal light and temperature fluctuations. For instance, leaf growth seasonality in other $Z$. marina populations has been attributed to annual variability in insolation (SandJensen 1975, Sand-Jensen \& Borum 1983, WiumAndersen \& Borum 1984), and aboveground biomass seasonality in other $C$. nodosa Mediterranean meadows to fluctuations in temperature (e.g. Terrados 1991). Studies in other $P$. oceanica meadows also revealed little seasonality in plant growth (e.g. Wittman 1984, Buia et al. 1992), albeit somewhat related to temperature fluctuations (Pirc 1985, Romero 1985, Alcoverro et al. 1995). The strong sensitivity of C. nodosa, the species showing the greatest seasonal- ity in module size and dynamics, to temperature may reflect the tropical origin of the genus Cymodocea compared to the temperate origin of the other taxa (cf. Phillips \& Menez 1988). The uniform growth of $Z$. marina, as indicated by quasi-constant $(\mathrm{CV}=12.6 \%)$ leaf and rhizome plastochron intervals, contrasts with the large seasonality in these properties reported for stands in other geographic regions, and may reflect the less variable, warmer temperatures and higher irradiances received in the NW Mediterranean when compared to north temperate seas.

Seagrass response to climate changes may be constrained by the rate of addition of modules. The length of the plastochron interval (i.e. the time elapsed between the formation of 2 consecutive modules; Erickson \& Michelini 1957), which is strongly speciesspecific (Duarte 1991), would limit the capacity of plants to respond to environmental variability. The short plastochron intervais (e.g. leaf́ plastochuon interval $=14 \mathrm{~d}$ ) of small seagrasses (e.g Zostera noltii) allows a faster plant response to seasonal fluctuations than the long module plastochron intervals (e.g. leaf plastochron incerval $=58$ d) of large seagrassos (Posidonia oceanica). Similarly, the seasonality in module plastochron intervals exhibited by these seagrasses and other species growing elsewhere (e.g. West \& Larkum 1979, Barber 1985, Brouns 1985) would lead to faster plant responses to climate changes in summer than in winter. The very long plastochron intervals of large seagrasses should effectively buffer seasonal environmental variability, leading to the limited seasonality observed for $P$. oceanica growth, and may uncouple seasonal growth pattems from environmental forcing.

The species-specific seasonal responses observed must reflect differences in the capacity to store resources and the extent of ramet integration among species, both processes being closely related to plant size. Seagrasses synthesise carbohydrates in excess during suitable high-light periods, and these are stored as starch in the rhizomes (e.g. Pirc 1985, Dawes \& Guiry 1992) to be used later under low-light conditions (e.g. Ralph et al. 1992). The dynamics of this carbohydrate pool has been extensively demonstrated for clonal terrestrial plants, such as Phragmites australis (Granéli et al. 1992), Rumex alpinus (Klimes et al. 1993), Clitonia borealis (Ashmun et al. 1982) and Fragaria chiloensis (Alpert \& Mooney 1986). The storage capacity of clonal plants is higher for large plants with thick and long-lived rhizomes than for small ones with thin and short-lived rhizomes (Ashmun et al. 1982). In addition, neighbour ramets within the clone can be integrated (Sarukhán \& Harper 1973) allowing some ramets to use the resources stored by others (cf. Pitelka \& Ashmun 
1985, Libes \& Boudouresque 1987, Tomasko \& Dawes 1989). The capacity for clonal integration, which can vary with season and water depth (Tomasko \& Dawes 1990), depends on the distance that resources must travel and on rhizome longevity (Pitelka \& Ashmun 1985). Large plants have longer-lived rhizomes (Duarte 1991) and shorter rhizome internodes than small plants, and when rhizome connections persist during, at least, the life span of the shoots, they are able to transport photoassimilates further apart than small plants (Pitelka \& Ashmun 1985). Hence, Posidonia oceanica, with thick $(10 \mathrm{~mm}$ diameter, Duarte 1991) and long-lived (>12 yr, Duarte 1991) rhizomes, should be able to store and transport enough carbohydrates to allow the plant to support a growth pattern relatively independent of environmental conditions. Cymodocea nodosa, with thinner ( $3 \mathrm{~mm}$, Duarte 1991) and perennial rhizomes (2.4 yr, Duarte 1991), should be able to store in its rhizomes the carbohydrates produced in excess during summer. These stored resources would increase (i.e. amplify) plant growth when the conditions for growth become favourable (in the spring). Similarly, the rhizomes of Zostera marina (3.5 mm, Duarte 1991) live for $1.5 \mathrm{yr}$ (Duarte 1991) and should also allow for some storage of resources to amplify the plant response to seasonal variability under favourable growth conditions, as has been demonstrated for reeds (Phragmites australis, Granéli et al. 1992). Conversely, the thin (1.3 mm, Duarte 1991) and short-lived $(<1 \mathrm{yr}$ ) rhizomes of $Z$. noltii should have a very limited storage of resources from one year to another. Growth of $Z$. noltii, therefore, should be coupled to seasonal or short-term time-scale resource variability, but it should not be able to amplify its response using stored resources. This postulated relationship between seagrass architecture and plant storage capacity closely agrees with the decreasing carbohydrate contents reported from $P$. oceanica, to Z. marina, C. nodosa, and Z. noltii rhizomes (Pirc 1985, 1989, Dawes \& Guiry 1992).

Allocation of resources to sexual reproduction, indicated here by flowering, could also influence the seasonal growth patterns observed. The decline in seagrass leaf, rhizome and root growth occurs about 1 mo after flowering (cross correlation, $r>0.6$ in all species; Fig. 8), when the plants are fruiting and temperature and irradiance are still rising (Fig. 2). This suggests production of flowers and fruits might involve a shift of resource allocation, probably nutrients from vegetative to reproductive structures resulting in a decrease in plant growth. However, seagrass inflorescences are green and they could supply some, or most, of the carbohydrate demand created by seed production (Harper 1977). The role of flowering and sexual reproduction as a factor causing seagrass seasonality has been suggested for tropical seagrasses (e.g. Zieman 1975, Gallegos et al. 1992).

The different influence of seasonality on seagrass leaf or rhizome growth across species has important implications for the seasonal biomass development of seagrass meadows. Large seagrasses (Posidonia oceanica) experience seasonal fluctuations in shoot growth while smaller ones (Cymodocea nodosa, Zostera marina and $Z$. noltii) exhibit seasonal variability both in shoot and rhizome growth. Rhizome growth is closely related with shoot recruitment, because new shoots are produced at regular intervals along the rhizome (Tomlinson 1974, Duarte 1991). Thus, fluctuations in rhizome growth involve fluctuations in shoot density. This suggests the existence of species-specific differences in the seasonal dynamics of seagrass meadows which appear to reflect the basic architecture of seagrass species. Seasonal fluctuations in the aboveground biomass of small seagrasses should reflect changes in both shoot size and shoot density, whereas it should mainly reflect changes in shoot size in larger species. This hypothesis has been tested for $Z$. marina, a relatively large seagrass, where seasonal changes in standing biomass are mainly derived from changes in shoot size rather than in shoot density when the meadow has not been highly disturbed during winter or early spring (Olesen \& Sand-Jensen 1994b). Because the cost of building rhizomes increases as the square of their diameter (Duarte 1991), small species with thin rhizomes can elongate their rhizomes and produce a substantial number of shoots every year at a much lower cost than large species with thick rhizomes, for which a seasonality of biomass based on changes in shoot density would be too resourcedemanding to be sustainable. The limited contribution of changes in shoot density (i.e. rhizome growth) to the seasonality of biomass of species with thick rhizomes postulated here is also in agreement with the long plastochrone intervals (Fig. 7) and life span of their shoots (Duarte 1991) Thus, the relative importance of seasonal changes in shoot or rhizome growth of different seagrass species may be intimately linked to their basic architecture.

In summary, these results demonstrate that seagrass seasonality in temperate areas derives from both extrinsic forcing (e.g. light and temperature), and intrinsic components (e.g. resource allocation, reproduction). The extrinsic forcing, mainly constrained by the latitudinal position of seagrass communities, would impose a common seasonal pattern on sympatric species. However, the intrinsic component of seagrass seasonality, which is intimately linked to seagrass size, involves species-specific differerences in their capacity to regulate the internal resource economy which may buffer, or amplify, the external seasonal forcing 
Acknowledgements. This work was founded by the CI1 CT91-0952 project from the Commission of the European Communities. We especially thank J. Pascual and Fundació Mas Badıa, which belongs to the Agrometeorological Network of Catalonia, for providing sea temperature and irradiance data, respectively. We are grateful to $T$. Alcoverro, $L$. Marbà and M. Gallegos for field assistance, and C. Sunyé and hıs family for hospitality. We also thank E. Ballesteros for identufying Zostera marina, and Kaj Sand-Jensen for useful comments on the manuscript.

\section{LITERATURE CITED}

Aioi K (1980) Seasonal change in the standing crop of eelgrass, Zostera marina L., in Odawa Bay, central Japan. Aquat Bot 8:343-354

Alcoverro T, Duarte CM, Romero J (1995) Annual growth dynamics of Posidonia oceanica: contribution of largescale versus local factors to seasonality. Mar Ecol Prog Ser 120:203-210

Alport D, Mooney MA (1986) Resource sharing among ramets in the clonal herb. Fragaria chilonensis. Oecologia 70: $227-233$

Ashmun JW. Thomas RJ, Pitelka LF (1982) Translocation of photoassimilates between sister ramets in two rhizomatous forect herbs. Ann Bot 49:403-415

Backman TW, Barilotti DC (1976) Irradiance reduction: effects on standing crops of the eelagass Zostera marina in a coastal lagoon. Mar Biol 34:33-40

Barber BJ (1985) Effects of elevated temperature on seasonal in situ leaf productivity of Thalassia testudinum Banks ex König and Syringodium filiforme Kützing. Aquat Bot 22: $61-69$

Bay D (1984) A field study of the growth dynamics and productivity of Posidonia oceanica (L.) Delile in Calvi Bay. Aquat Bot 20:43-64

Brouns JJWM (1985) A preliminary study of the seagrass Thalassodendron ciliatum (Forssk.) den Hartog from Eastern Indonesia: biological results of the Snellius II Expedition. Aquat Bot 23:249-260

Buia MC, Zupo V, Mazzel)ā L (1992) Primary production and growth dynamics in Posidonia oceanica. PSZN I: Mar Ecol $13: 2-16$

Cayé $G$, Rossignol M (1983) Etude des variations saisonnières de la croissance des feuilles et des racines de Posidonia oceanica. Mar Biol 75:79-88

Dawes CJ, Guiry MD (1992) Proximate constituents in the seagrasses Zostera marina and Zostera noltii in Ireland: seasonal chnages and the effect of blade removal. PSZN I Mar Ecol 13:307-315

Den Hartog C (1970) The seagrasses of the world. North Holland Publ, Amsterdam

Duarte CM (1989) Temporal biomass variability and production/biomass relationships of seagrass communities. Mar Ecol Prog Ser 51:269-276

Duarte CM (1991) Allometric scaling of seagrass form and productivity. Mar Ecol Prog Ser 77:289-300

Duarte CM, Marbà N, Agawin N, Cebrián J, Enríquez S, Fortes MD, Gallegos ME, Merino $M$, Olesen B, SandJensen K, Uri J, Vermaat J (1994) Reconstruction of seagrass dynamics: age determinations and associated tools for the seagrass ecologist. Mar Ecol Prog Ser 107:195-209

Erickson RO, Michelini. FJ (1957) The plastochron index. Am $J$ Bot 44:297-305

Evans AS, Webb KL, Penhale PA (1986) Photosynthetic temperature acclimatation in two coexisting seagrasses,
Zostera marina L. and Ruppia maritima L. Aquat Bot 24: 185- 197

Gallegos ME, Menno M., Marbà N, Duarte CM (1992) Flowering of Thalassia tostudinum Banks ex König in the Mexlcan Caribbean: age-dependence and interannual variability. Aquat Bot 43:249-255

Granéli W, Weisner SEB, Sytsma MD (1992) Rhizome dynamics and resource storage in Phragmites australis. Wetl Ecol Manag 1:239-247

Harper JL (1977) Population biology of plants. Academic Press, London

Ibarra-Obando SE (1989) Las praderas de pastos marinos del Pacífico Mexicano, con énfasis en Zostera marina L. In: de la Rosa-Vélez J, González Farias F (eds) Temas de oceanografía biológica en México. Univ Autónoma de Baja California, Ensenada, p 1-20

Jacobs RPWM (1979) Distribution and aspects of the production and biomass of eelgrass, Zostera marina L. at Roscoff France. Aquat Bot 7:151-172

Jacobs RPWM, Hegger HH, Ras-Willems A (1982) Seasonal variations in structure of a Zostera community on tidal flats in the SW Netherlands, with special reference to the benthic fauna. Proc $K$ Ned Akad Wel (Sect C) 86: $347-357$

Kentula ME, McIntire CD (1986) The autecology and production dynamics of eelgrass (Zostera marina L.) in Netarts Bay, Oregon. Estuaries 9:188-199

Klimes L, Klımesová j, Gsbornuvá I (1993) Regencration capacity and carbohydrate reserves in a clonal plant Rumex alpinus: effect of burial. Vegetatio 109:153-160

Lalumière R, Messier D, Fournier JJ, McRoy CP (1994) Eelgrass meadows in a low arctic environment in the northeast coast of James Bay, Québec. Aquat Bot 47:303-315

Libes M, Boudouresque CF (1987) Uptake and long-distance transport of carbon in the manne phanerogam Posidonia oceanica. Mar Ecol Prog Ser 38:177-186

Marbà N, Cebrián J, Enriquez S, Duarte CM (1994) Migration of large-scale subaqueous bedforms measured with seagrasses (Cymodocea nodosa) as tracers. Limnol Oceanogr 39:126-133

Marbà N, Duarte CM (1994) Growth response of the seagrass Cymodocea nodosa to experimental burial and erosion. Mar Ecol Prog Ser 107:307-311

McRoy CP (1966) The standing stock and ecology of eelgrass, Zostera marina L., Izembek lagoon. Alaska. MSc thesis, University of Washington, Seattle

Mukai H, Aioi K, Ishida Y (1980) Distribution and biomass of eelgrass (Zostera marina L.) and another seagrasses in Odawa Bay, Central Japan. Aquat Bot 8:337-342

Nienhuis PH, De Bree BHH (1980) Production and growth dynamics of eelgrass (Zostera marina) in Brackish Lake Grevelingen (The Netherlands). Neth $J$ Sea Res 14: $335-431$

Olesen B, Sand-Jensen K (1994a) Demography of shallow eelgrass (Zostera marina) populations: shoot dynamics and biomass development. J Ecol 82:379-390

Olesen B, Sand-Jensen K (1994a) Biomass-density patterns in the temperate seagrass Zostera marina. Mar Ecol Prog Ser 109:283-291

Orth RJ, Moore K (1986) Seasonal and year-to-year variations in the growth of Zostera marina L. (eelgrass) in the lower Chesapeake Bay. Aquat Bot 24:335-431

Ott JA (1979) Persistence of a seasonal growth rhythm in Posidonia oceanica (L.) Delile under constant conditions of temperature and lllumination. Mar Biol Lett 1:99-104

Ott JA (1980) Growth and production in Posidonid oceanica (L.) Delile. PSZN I: Mar Ecol 1:47-64 
Pedersen MF, Borum J (1993) An annual nitrogen budget for a seagrass Zostera marina population. Mar Ecol Prog Ser $101: 169-177$

Peduzzi P. Vukovic A (1990) Primary production of Cymodocea nodosa in the Gulf of Trieste (Northern Adriatic Sea): a comparison of methods. Mar Ecol Prog Ser 64:197-207

Pérez M (1989) Fanerogamas marinas en sistemas estuáricos: producción, factores limitantes, y algunos aspectos del ciclo de nutrientes. PhD thesis, Universidad de Barcelona

Pérez M, Duarte CM, Romero J, Sand-Jensen $\mathrm{K}$, Alcoverro T (1995) Growth plasticity in Cymodocea nodosa stands: the importance of nutrient supply. Aquat Bot 47:249-264

Pérez M, Romero, J (1992) Photosynthetic response to light and temperature of the seagrass Cymodocea nodosa and the prediction of its seasonality. Aquat Bot 43:51-62

Pérez M, Romero J, Duarte CM, Sand-Jensen K (1991) Phosphorus limitation of Cymodocea nodosa growth. Mar Biol 109:129-133

Pérez-Llorens JL (1991) Estimaciones de biomasa y contenido interno de nutrientes, ecofisiología de incorporación de carbono y fosfato en Zostera noltii Hornem. PhD thesis, University of Málaga

Pérez-Llorens JL, Niell FX (1993) Seasonal dynamics of biomass and nutrient content in the intertidal seagrass Zostera noltii Hornem. from Palmones River estuary, Spain. Aquat Bot 46:49-66

Pergent G, Boudouresque CF, Crouzet A, Meinesz A (1989) Cyclic changes along Posidonia oceanica rhizomes (lepidochronology): present state and perspectives. PSZN I: Mar Ecol 10:221-230

Phillips RC (1972) Ecological life history of Zostera marina (L.) (eelgrass) in Puget Sound, Washington. PhD dissertation, University of Washington, Seattle

Phillips RC, McMillan RC, Bridges C (1983) Phenology of eelgrass Zostera marina L., along latitudinal gradients in North America. Aquat Bot 15:145-156

Phillips RC, Meñez EG (1988) Seagrasses, Vol 34. Smithsonian Institution Press, Washington, DC

Pirc H (1985) Growth dynamics in Posidonia oceanica (L.) Delile I. Seasonal changes of soluble carbohydrates, starch, free amino acids, nitrogen and organic anions in diferent parts of the plant. PSZN I: Mar Ecol 6:141-165

Pirc H (1989) Seasonal changes in soluble carbohydrates, starch, and energy content in Mediterranean seagrasses. PSZN I: Mar Ecol 10:97-105

Pitelka LF, Ashmun JW (1985) Physiology and integration of ramets in clonal plants. In: Jeremy BC, Buss LW, Cook RE (eds) Population biology and evolution of clonal organisms. Yale University Press, New Haven, p 399-435

Ralph PJ, Burchett MD, Pulkowik A (1992) Distribution of extractable carbohydrate reserves within the rhizome of the seagrass Posidonia australis Hook. f. Aquat Bot 42: 385-392

Robertson Al, Man KH (1984) Disturbance by ice and life-history adaptations of the seagrass Zostera marina. Mar Biol 80:131-141

Roman CT, Able KW (1988) Production ecology of eelgrass (Zostera marina L.) in a Cape Cod salt marsh-estuarine

Thus article was presented by G. W. Thayer (Senior Editorial Advisor), Beaufort, North Carolina, USA system, Massachusetts. Aquat Bot 32:353-363

Romero J (1985) Estudio ecológico de las fanerógamas de la costa Catalana: producción primaria de Posidonia oceanica (L.) Delile en las Islas Medes. PhD thesis, Universidad de Barcelona

Sand-Jensen K (1975) Biomass, net production and growth dynamics in an eelgrass (Zostera marina L.) population in Vellerup Vig, Denmark. Ophelia 14:185-201

Sand-Jensen K, Borum J (1983) Regulation of growth of eelgrass (Zostera marina L.) in Danish coastal waters. Mar Technol Soc J 17:15-21

Sarukhán J, Harper JL (1973) Studies on plant demography: Ranunculus repens L., $R$. bulbosus L., and $R$. acris L. I. Population flux and survivorship. J Ecol 61:675-716

Terrados J (1991) Crecimiento y producción de las praderas de macrófitos del Mar Menor, Murcia. PhD thesis, Universid.ad de Murcia

Terrados J, Ros JD (1992) Growth and primary production of Cymodocea nodosa (Ucria) ascherson in a Mediterranean coastal lagoon: the Mar Menor (SE Spain). Aquat Bot 43: $63-74$

Thom R (1990) A review of eelgrass (Zostera marina L.) transplanting projects in the Pacific Northwest. NW Environm J 6:121-137

Thorne-Miller B, Harlin MM (1984) The production of Zostera marina $\mathrm{L}$. and other submerged macrophytes in a coastal lagoon in Rhode Island, U.S.A. Botanica Mar 27:539-546

Tomasko DA, Dawes CJ (1989) Evidence for physiological integration between shaded and unshaded short shoots of Thalassia tesiudinum. Mar Ecol Prog Ser 54:299-305

Tomasko DA, Dawes CJ (1990) Influences of season and water depth on the clonal biology of the seagrass Thalassia testudinum. Mar Biol 105:345-351

Tomlinson PB (1974) Vegetative morphology and meristem dependence. The foundation of productivity in seagrasses. Aquaculture 4:107-130

Vermaat JE, Hoostmans MJM, Nienhuis PH (1987) Seasonal dynamics and leaf growth of Zostera noltii Honem., a perennial intertidal seagrass. Aquat Bot 28:287-299

Vidondo B, Duarte CM (1995) Seasonal growth of Codium bursa, a slow-growing Mediterranean magroalga: in situ experimental evidence of nutrient limitation. Mar Ecol Prog Ser 123:185-191

West RJ, Larkum AWD (1979) Leaf productivity of the seagrass, Posidonia australis, in Eastern Australian waters. Aquat Bot 7:57-65

White (1979) The plant as a metapopulation. A Rev Ecol Syst 10:109-145

Wittman KJ (1984) Temporal and morphological variations of growth in a natural stand of Posidonia oceanica (L.) Delile. PSZN I: Mar Ecol 5:301-316

Wium-Andersen S, Borum J (1984) Biomass variation and autotrophic production of an epiphyte-macrophyte community in a coastal danish area: I. Eelgrass (Zostera marina L.) biomass and net production. Ophelia 23:33-46

Zieman JC (1975) Seasonal variation of turtle grass, Thalassia testudinum Konig, with reference to temperature and salinity effects. Aquat Bot 1:107-123

Manuscript first received: October 15, 1994

Revised version accepted: October 20, 1995 